\title{
PENGARUH TINGKAT INTERNET SELF-EFFICACY, PENGALAMAN MENGAJAR DAN USIA GURU TERHADAP PEGUASAAN KOMPUTER DALAM STRATEGI PEMBELAJARAN DARING
}

\author{
Eka Budhi Santosa ${ }^{1}$, , Sarwanta ${ }^{2)}$ \\ ${ }_{1}$ Manajemen Informatika, AMIK Harapan Bangsa Surakarta \\ email: ekabudhis.journal@gmail.com \\ ${ }^{2}$ SMPN 1 Delanggu \\ email: sarwantaanto@gmail.com
}

\begin{abstract}
The purpose of this research was to see what teacher characteristic variables had the most influence on computer mastery in online learning strategies. This research uses descriptive verification method with quantitative analysis approach. The number of respondents was 319 junior high school teachers. Data analysis used logistic regression ordinal with software $R$. The results of this study indicate that there is an effect of teacher age (X1), teaching experience (X2), and internet self-efficacy (X3) together on the level of computer mastery in online learning. The ordinal logistic regression model that is formed for the level of teacher mastery in online learning is $Y_{1}(X)=5.29+0.033 X_{1}-0.5 X_{2}-0.03$ $X_{3} ; Y_{2}(X)=3.88+0.033 X_{1}-0.5 X_{2}-0.03 X_{3} ; \quad Y_{3}(X)=3.06+0.033 X_{1}-0.5 X_{2}-0.03 X_{3}$; $(X)=1.75+0.033 X_{1}-0.5 X_{2}-0.03 X_{3}$. The second result of this study shows that the factor that influences the level of mastery of teachers in online learning is the teaching experience variable. The contribution of this research to online learning research is the need to provide manipulation of computer-assisted teaching experiences for teachers in online learning environments. The recommended manipulation of experience is education and training. Suggestions for further researchers are the need to add other independent variables related to teacher characteristics that can affect the level of teacher computer mastery in online learning strategies.
\end{abstract}

Keyword: age, teaching experience, internet self-efficacy, online learning

\begin{abstract}
Abstrak: Tujuan penelitian ini adalah melihat variable karakteristik guru apa yang paling berpengaruh terhadap peguasaan komputer dalam strategi pembelajaran daring. Penelitian ini menggunakan metode deskriptif verifikatif dengan pendekatan analisis kuantitatif. Jumlah responden adalah 319 guru Sekolah Menengah Pertama. Analisis data menggunakan regresi logistic ordinal dengan software $R$. Hasil penelitian ini menunjukan bahwa terdapat pengaruh usia guru (X1), pengalaman mengajar (X2), dan internet selfefficacy (X3) secara bersama sama terhadap tingkat penguasaan komputer dalam pembelajaran daring. Model regresi logistik ordinal yang terbentuk untuk tingkat penguasaan guru dalam pembelajaran daring adalah $Y_{1}(X)=5.29+0.033 X_{1}-0.5 X_{2}-0.03 X_{3}$; $Y_{2}(X)=3.88+0.033 X_{1}-0.5 X_{2}-0.03 X_{3} ; \quad Y_{3}(X)=3.06+0.033 X_{1}-0.5 X_{2}-0.03 X_{3} ; \quad(X)=1.75+$ $0.033 X_{1}-0.5 X_{2}-0.03 X_{3}$. Hasil kedua dari penelitian ini menujukan bahwa faktor yang berpengaruh terhadap tingkat penguasaan guru dalam pembelajaran daring adalah variabel pengalaman mengajar. Kontribusi penelitian ini bagi penelitian pembelajaran daring adalah perlunya diberikan manipulasi pengalaman mengajar berbantuan komputer bagi guru dalam lingkungan pembelajaran daring. Manipulasi pengalaman yang dianjurkan adalah pendidikan dan pelatihan. Saran bagi peneliti selanjutnya adalah perlunya menambahkan variable bebas lain terkait dengan karakteristik guru yang bisa mempengaruhi tingkat peguasaan komputer guru dalam strategi pembelajaran daring.
\end{abstract}

Kata kunci: usia, pengalaman mengajar, internet self-efficacy, pembelajaran daring 


\section{PENDAHULUAN}

Pandemi Covid-19 menjadi tantangan besar bagi sistem pendidikan di Indonesia. Kondisi ini telah memaksa perubahan secara fundamental pada strategi pembelajaran, cara belajar siswa dan gaya mengajar guru dari yang biasa dilakukan sebelumnya (Sadikin \& Hamidah, 2020). Berbagai strategi pembelajaran yang dahulu menitik beratkan pada tatap muka di dalam kelas, harus berganti dengan berbasis daring. Penggunaan media pembelajaran berbasis android dilakukan untuk meningkatkan hasil belajar siswa (Amin \& Mayasari, 2015). Perubahan-perubahan ini menimbulkan banyak kendala yang harus diselesaikan oleh guru, siswa dan pihakpihak yang terkait dengan pembelajaran. Namun demikian studi tentang faktor-faktor yang mempengaruhi keberhasilan pembelajaran digital banyak dilakukan hanya terhadap siswa, tetapi jarang meneliti faktor guru atau konteks pembelajaran lainnya (Blackwell, Lauricella, \& Wartella, 2014).

Guru merupakan kunci penanganan krisis pembelajaran akibat perubahan lingkungan belajar. Guru merupakan simpul pembelajaran yang mengenal karakteristik siswa dan lingkungan belajarnya (Daniel, 2020). Sementara itu, keberhasilan strategi pembelajaran berbantuan komputer ditentukan oleh faktor yang dari dalam diri guru dan juga factor dari luar diri guru (Moos \& Azevedo, 2009). Keyakinan guru terhadap keberhasilan pembelajaran berbasis digital merupakan kunci keberhasilan proses pembelajaran berbantuan teknologi informasi (Mumtaz, 2000; Cassidy \& Eachus, 2002). Namun demikian, guru juga harus mendapat dukungan dari stake holder lain yang terkait seperti kepala sekolah, orang tua siswa dan pemerintah. Selain itu factor sarana dan prasarana belajar daring juga merupakan penentu keberhasilan pembelajaran daring (Herliandry, Nurhasanah, Suban, \& Kuswanto, 2020).

Penelitian terdahulu menunjukan bahwa internet self-efficacy berhubungan erat dengan faktor sikap dan faktor psikologis setiap orang (Moos \& Azevedo, 2009). Hal itu berarti bahwa pribadi yang mendapat perlakuan pemodelan sikap berupa pembiasaan pemanfaatan komputer akan cenderung memiliki internet selfefficacy yang lebih tinggi dibanding dengan yang tidak mendapat perlakuan pemodelan(Cassidy \& Eachus, 2002). Penelitian tedahulu menunjukkan bahwa tingkat self efficacy guru menentukan keberhasilan desain pembelajaran berbantuan computer dan teknologi informasi (Jaber \& Moore, 1999).

Menurut Mumtaz, (2000) faktor yang mempengaruhi keputusan guru untuk menggunakan teknologi informasi dan komputer di dalam pembelajaran adalah meliputi akses kepada sumber daya pembelajaran yang ada, kualitas komputer baik perangkat lunak maupun perangkat kerasnya, lingkungan sekolah dan kebijakan pemerintah. Faktor intenal guru antara lain self efficacy, pengalaman mengajar, komitmen guru pada pembelajaran berkualitas dan latar belakang pendidikan guru. Faktor-faktor tersebut menjadi pertimbangan guru dalam membuat strategi pembelajaran berbasis digital.

Pengalaman seseorang berdampak pada penurunan tingkat kecemasan diri (computer enxiety) dalam lingkungan pembelajaran daring (Sam, Othman, \& Nordin, 2005). Akibat tingkat kecemasan yang rendah adalah sikap positif terhadap lingkungan pembelajaran daring. Dengan sikap positif maka proses pembelajaran akan bisa lebih optimal. Penelitian menunjukan bahwa semakin tingginya tingkat kecemasan seseorang terhadap penggunaan komputer 
akan menurunkan kinerjanya. Hal itu disebabkan oleh pengaruh faktor fisiologis dan daya pikir seseorang yang melemah (Heinssen, Glass, \& Knight, 1987). Guru yang berpengalaman akan mampu mengatasi berbagai hambatan yang datang dari dalam dirinya maupun dari luar dirinya sebagai bentuk profesionalisme seorang guru (Wahlstrom \& Louis, 2008).

Beberapa sarjana mengelompokan manusia berdasar pada latar belakang sikap terhadap teknologi informasi menjadi dua, yaitu digital native dan digital immigrant (Prensky, 2001; Wang, Myers, \& Sundaram, 2013). Terdapat dua karakteristik yang biasa digunakan untuk mendefinisikan perbedaan antara keduanya yaitu usia dan aksesibilitas. Kriteria berdasar pada batas tahun kelahiran, beberapa ahli memiliki pendapat yang bervariasi yaitu antara akhir tahun 1970-an hingga akhir tahun 1990-an (Wang et al., 2013). Ciri generasi digital native adalah mereka sangat familiar dengan hal-hal terkait digital, seperti komputer, video game, pemutar music digital, video, telepon selular dan lain sebagainya. Sedangkan digital immigrant adalah orang-orang yang memerlukan kemampuan beradaptasi dengan teknologi informasi (Hills, 2010; Wang et al., 2013). Namun demikian, teori tersebut ditentang oleh banyak ahli (Brown \& Czerniewicz, 2010; Jones \& Czerniewicz, 2010). Berdasar kajiannya, Wang et al., (2013) mengatakan bahwa pembagian digital native dan digital immigrant tidak tepat. Dia lebih mempreskripsikan sebagai kontinum antara dua kelompok dan kontinum ini paling baik dikonseptualisasikan sebagai kontinum "kefasihan digital". Hal itu dikarenakan akan menjadi terlalu sederhana untuk menyatakan digital nativity atau kefasihan digital sematamata dari faktor usia dan aksesibilitas. Karena kefasihan digital memiliki faktor lainnya yaitu faktor psikologis, organisasi dan sosial.

Tujuan penelitian ini adalah ingin melihat variable karakteristik guru mana yang paling berpengaruh terhadap peguasaan komputer dalam strategi pembelajaran daring. Tujuan tersebut merupakan jawaban dari hipotesis yang menduga bahwa : a) Tidak ada pengaruh antara usia guru $\left(\mathrm{X}_{1}\right)$, pengalaman mengajar $\left(\mathrm{X}_{2}\right)$, dan internet self-efficacy $\left(\mathrm{X}_{3}\right)$ guru terhadap tingkat penguasaan komputer dalam pembelajaran daring. b) Terdapat minimal satu dari variabel bebas $\left(\mathrm{X}_{1}, \mathrm{X}_{2}, \mathrm{X}_{3}\right)$ berpengaruh terhadap tingkat penguasaan komputer dalam pembelajaran daring. Hal itu didasarkan pada banyak penelitian sebelumnya yang menyimpulkan bahwa internet self-efficacy merupakan faktor paling berpengaruh terhadap peguasaan komputer dalam strategi pembelajaran daring (Compeau \& Higgins, 1995; Igbaria \& Iivari, 1995; Yeşilyurt, Ulaş, \& Akan, 2016).

\section{METODE PENELITIAN}

Penelitian ini menggunakan metode deskriptif verifikatif dengan pendekatan analisis kuantitatif. Variabel-variabel yang digunakan dalam penelitian ini disesuaikan dengan data primer yaitu usia guru, pengalaman mengajar guru dan tingkat internet self-efficacy dari guru SMP yang tergabung dalam Musyawarah Guru Mata Pelajaran (MGMP) IPS. Sedangkan variable terpengaruhnya adalah tingkat penguasaan komputer dari para guru dalam strategi pembelajaran daring. Jumlah responden adalah 319 guru yang berasal dari beberapa sekolah di pulau Jawa dan Luar pulau Jawa. Pengambilan data dilakukan dengan mengirimkan link google form ke WhatsApp grup MGMP Edukasi IPS. Proses pengambilan data dilakukan dari tanggal 4 Juli sampai dengan tanggal 8 Juli 2019 . 
Teknik sampling dalam penelitian ini menggunakan teknik nonprobability incidental.

Tabel 1. Kategori variable penelitian

\begin{tabular}{|c|c|c|}
\hline Variabel & Label & Kategori \\
\hline $\boldsymbol{Y}$ & $\begin{array}{l}\text { Tingkat } \\
\text { penguasaan } \\
\text { komputer dalam } \\
\text { strategi } \\
\text { pembelajaran } \\
\text { daring }\end{array}$ & $\begin{array}{l}4=\text { Sangat } \\
\text { Tinggi } \\
3=\text { Tinggi } \\
2=\text { Cukup } \\
1=\text { Kurang } \\
0=\text { Sangat } \\
\text { kurang }\end{array}$ \\
\hline$X_{1}$ & Usia & (Kontinu) \\
\hline$X_{2}$ & $\begin{array}{l}\text { Pengalaman } \\
\text { mengajar }\end{array}$ & $\begin{array}{l}4=>20 \text { tahun } \\
3=11-20 \text { tahun } \\
2=5-10 \text { tahun } \\
1=<5 \text { tahun }\end{array}$ \\
\hline$X_{\mathrm{I}}$ & $\begin{array}{l}\text { Tingkat self } \\
\text { efikasi }\end{array}$ & (Kontinu) \\
\hline
\end{tabular}

skala internet self-efficacy (Internet Selfefficacy Scale / ISS) yang dibuat oleh Kim \& Glassman, (2013). Kuesioner terdiri dari 20 pernyataan yang diterjemahkan dari bahasa aslinya yaitu bahasa Ingris ke dalam bahasa Indonesia. Setelah dilakukan uji validitas, ditemukan bahwa $r$ hitung $\geq r$ table, yang berarti bahwa instrumen dinyatakan valid.

Metode analisis dalam penelitian ini dimulai dengan melakukan analisis statistika deskriptif data untuk mengetahui karakteristik tingkat penguasaan pembelajaran daring yang meliputi variable terikat $(Y)$ dan variable predictor $\left(X_{1}, X_{2}, X_{3}\right)$ yang meliputi usia guru, pengalaman mengajar dan tingkat internet self-efficacy guru. Kemudian melakukan analisis regresi logistic ordinal untuk memperolah faktorfaktor yang memengaruhi tingkat penguasaan pembelajaran daring, sebagai berikut: a) melakukan estimasi parameter; b) pembentukan model regresi logistik ordinal dari seluruh variable bebas yang berpengaruh dengan variable terikat $(Y)$; c) melakukan pengujian secara serentak model regresi logistik ordinal; d) melakukan pengujian secara parsial model regresi logistik ordinal; e) menyatakan model akhir yaitu dengan menggunakan model odd proporsional; dan f) melakukan interpretasi terhadap model yang diperoleh.

\section{HASIL DAN PEMBAHASAN}

Analisis data menggunakan regresi logistic ordinal dengan software R. Regresi Logistik Ordinal merupakan model regresi yang banyak dipakai dalam menyelesaikan kasus regresi antara variabel terikat (Y) dengan satu atau lebih variable bebas (X), dimana variabel Y merupakan data kualitatif yang berbentuk polikotomus berskala ordinal (Pentury, Aulele, \& Wattimena, 2016).

Data responden sebanyak 319 guru, selanjutnya dilakukan analisis regresi logistik ordinal. Analisis pertama dilakukan pengujian secara serentak tiga variabel bebas yang diamati dalam penelitian. Setelah itu dilakukan pengujian variabel-variabel bebas apa saja yang signifikan berpengaruh terhadap tingkat penguasanaan komputer dalam pembelajaran daring. Pada setiap pengujian parameter secara serentak diperoleh apakah keseluruhan variabel bebas yang digunakan memiliki pengaruh terhadap variabel terikat.

Tabel 2. Hasil Likelihood Ratio test

\begin{tabular}{ccc}
\hline $\mathrm{G}$ & $\mathrm{Db}$ & $\mathrm{p}$-value \\
\hline 8.46 & 3 & 0.0374 \\
\hline
\end{tabular}

Berdasarkan Tabel dapat dilihat bahwa pada saat semua variabel bebas dimasukkan ke dalam model, nilai signifikan $(p-$ value $)=0.0374$. Hal itu berarti nilai $p$ value lebih kecil dari $(<) \alpha$, dimana nilai $\alpha=$ 0.05 (tingkat kepercayaan 95\%). Dengan hasil tersebut dimana nilai signifikan (pvalue) lebih kecil dari $\alpha$, maka berarti bahwa $\mathrm{H}_{0}$ ditolak.

Hasil tersebut menunjukan bahwa terdapat minimal satu variabel bebas yang 
berpengaruh terhadap tingkat penguasaan komputer dalam pembelajaran daring. Dari ketiga variable bebas yang ada, yaitu usia guru, pengalaman mengajar dan intenet self efficacy secara logis salah satu memiliki pengaruh paling kuat kepada guru dalam penguasaan komputer dalam pembelajaran daring guru. Konsekuensi dari hasil tersebut selanjutnya dilakukan pengujian parameter secara parsial.

Hipotesis kedua dalam penelitian ini adalah "Terdapat minimal satu dari variabel bebas $\left(\mathrm{X}_{1}, \mathrm{X}_{2}, \mathrm{X}_{3}\right)$ berpengaruh terhadap tingkat penguasaan komputer dalam pembelajaran daring $\left(H_{1}\right.$ : paling sedikit ada satu $\left.\neq 0\right)$." Pengujian untuk parameter secara parsial ini dilakukan dengan rumusan sebagai berikut: a). Tidak ada pengaruh variabel bebas yang diuji terhadap variabel terikat $\left(H_{0}: \beta_{R}=0\right)$. b). Terdapat pengaruh variabel bebas yang diuji terhadap variabel terikat $\left(H_{1}: \beta_{\mathrm{E}} \neq 0\right)$.

Berdasarkan estimasi parameter maka fungsi logitnya dapat dituliskan seperti pada tebel 3 berikut :

Tabel 3. Regresi fungsi Logit

\begin{tabular}{lcccc}
\hline & Koef & SE Coef & Z & p-vall \\
\hline nstanta 1 & 5.29 & 1.41 & 3.76 & 0.000 \\
\hline nstanta 2 & 3.88 & 1.38 & 2.80 & 0.005 \\
\hline nstanta 3 & 3.06 & 1.38 & 2.22 & 0.026 \\
\hline nstanta 4 & 1.75 & 1.37 & 1.28 & 0.200 \\
\hline ia $\left(X_{1}\right)$ & 0.033 & 0.02 & 1.24 & 0.213 \\
$\begin{array}{l}\text { igalaman } \\
\text { rja }\left(X_{2}\right)\end{array}$ & -0.50 & 0.24 & -2.11 & 0.03 : \\
$\begin{array}{l}\text { ernet Self } \\
\text { icacy }\left(X_{\mathrm{I}}\right)\end{array}$ & -0.03 & 0.01 & -1.81 & 0.06 \\
\hline
\end{tabular}

Berdasarkan tabel 3 di atas dapat diketahui bahwa terdapat satu variabel bebas yang berpengaruh secara signifikan (pvalue $<0.05$ ) terhadap tingkat peguasaan komputer dalam strategi pembelajaran daring yaitu variabel pengalaman mengajar $\left(X_{2}\right)$. Dari pengujian secara parsial maka model regresi logistik yang diperoleh adalah sebagai berikut:

$$
\begin{aligned}
& Y_{1}(X)=5.29+0.033 X_{1}-0.5 X_{4}-0.03 X_{3} \\
& Y_{4}(X)=3.88+0.033 X_{1}-0.5 X_{4}-0.03 X_{3} \\
& Y_{3}(X)=3.06+0.033 X_{1}-0.5 X_{4}-0.03 X_{\text {马 }} \\
& Y_{4}(X)=1.75+0.033 X_{1}-0.5 X_{2}-0.03 X_{\text {ज }}
\end{aligned}
$$

Pada model regresi logistik, yang digunakan untuk interpretasi koefisien adalah odds ratio. Nilai odds ratio merupakan rasio antara kecenderungan (resiko) terjadinya suatu peristiwa dalam kelompok kasus dengan kelompok kontrol. Nilai odds ratio masing-masing koefisien pada model terbaik yang diperoleh yaitu model tingkat peguasaan komputer dalam strategi pembelajaran daring yang dipengaruhi oleh variabel usia, pengalaman kerja, dan internet self efficacyi ditunjukan dalam table 4 berikut:

Tabel 4. Nilai Odds Ratio

\begin{tabular}{ccc}
\hline Variabel & Koef & Odds Ratio \\
\hline Pengalaman $\left(X_{2}\right.$ & -0.5 & 0.606
\end{tabular}

Berdasarkan Tabel dapat diinterpretasikan bahwa Odds Ratio $X_{2}$ (pengalaman mengajar $)=0.606$. Hal itu berarti dengan perubahan pengalaman guru akan mengakibatkan penurunan tingkat penguasaan pembelajaran daring sebesar 0.606 kali.

Hasil penelitian ini sesuai dengan penelitian sebelumnya yang menempatkan pengalaman sebagai hal penting dalam proses pembelajaran untuk meningkatkan profesionalisme seorang guru (Bransford, Brown, \& Cocking, 2000). Pengalaman guru dalam kegiatan pembelajaran disertai keinginan intrinsic guru untuk lebih professional dalam pekerjaanya menjadi factor penentu seorang guru mampu mengatasi kendala yang dihadapi terkait dengan teknologi digital (Ramsden, 1991). Terdapat istilah refleksi pembelajaran seperti diungkapkan oleh Boud, Keogh, \& Walker, (2013) dimana pengalaman bisa diubah menjadi sebuah pembelajaran. Pengalaman bisa berupa teladan, pekerjaan yang dilakukan berulang, atau pernah dilakukan, hal yang dialami dan keberadaan 
orang dalam lingkungan tertentu. Refleksi pembelajaran inilah yang menjadi banyak kasus dijumpai bahwa orang yang belajar secara akademik belum tentu lebih terampil atau lebih pandai dalam suatu hal khusus dibanding dengan orang yang mengalami sendiri ilmu yang dipelajari tersebut. Hal itu relevan dengan pengalaman mengajar guru telah mampu mengatasi berbagai kesulitan dalam penggunaan strategi pembelajaran daring.

Beranjak dari dinamika perkembangan teknologi informasi saat ini, bagaimana guru dapat terus tumbuh dan berkembang dalam perjalanan pembelajaran mereka sendiri agar bisa mendesain pembelajaran dikelasnya yang mengakibatkan siswa-siswi yang diajarnya bisa belajar lebih baik lagi. Kebanyakan siswa akan menyadari bahwa mereka belajar dari pengalaman pembelajaran sebelumnya, tetapi bagaimana pembelajaran itu terjadi dan bagaimana hal itu dapat dimanfaatkan lebih optimal menjadi tantangan tersendiri bagi guru. Demikian pula bagaimana menyusun perangkat pembelajaran, strategi dan lingkungan belajar agar proses berpikir yang mengarah pada penyerapan informasi baru dalam proses pembelajaran bisa berlangsung optimal. Pengetahuan baru yang selanjutnya bisa tertransformasi menjadi konsep dan model mental baru dan pada akhirnya cara perilaku baru merupakan tujuan pembelajaran yang sangat penting dalam proses pembelajaran (Bancroft, 2014).

Namun demikian peneliti lain menemukan bahwa terdapat korelasi positif yang signifikan antara pengalaman dengan komputer sebelumnya dengan computer selfefficacy orang tersebut (Hill, Smith, \& Mann, 1987). Mereka menjelaskan bahwa pengalaman hanya memengaruhi niat perilaku untuk menggunakan komputer secara tidak langsung melalui computer self- efficacy. Kualitas pengalaman menggunakan komputer menjadi lebih penting. Pengalaman masa lalu yang positif dengan komputer akan meningkatkan self-efficacy, sedangkan pengalaman negatif akan mengurangi self-efficacy. Namun demikian, penelitian lain mengemukakan bahwa meskipun seseorang memiliki pengalaman positif dengan komputer tapi hal itu tidak serta merta mampu meningkatkan computer self-efficacy (Ertmer, Evenbeck, Cennamo, \& Lehman, 1994). Hal lain yang harus diperhatikan adalah kualitas aktual pengalaman dalam interaksinya dengan komputer, misalnya banyaknya waktu yang digunakan untuk mengerjakan tugas-tugas dengan komputer. Dengan kata lain, kualitas pengalamanlah yang merupakan faktor penting yang menentukan computer selfefficacy dibandingkan kuantitas pengalamannya dengan komputer.

Penelitian lainnya sedikit bebeda dimana penekannya adalah pengalaman pelatihan komputer secara signifikan akan meningkatkan computer self-efficacy (Torkzadeh \& Koufteros, 1994). Hal itu berarti efikasi diri tidak didapatkan secara acak, tetapi terstruktur dalam sebuah pelatihan. Guru yang mendapatkan pelatihan secara terstruktur mengenai strategi pembelajaran daring, baik teknik pembuatan kurikulum, media pembelajaran digital yang digunakan maupun evaluasi pembelajaran berbasis digital akan meningkatkan kualitas pembelajaran berbasis digital. Hal ini yang belum mendapat penjelasan dalam penelitian ini. Karena penelitian ini lebih focus kepada pengalaman mengajar guru. Namun pengala, an tersebut tidak bisa dipisahkan dari berbagai pelatihan yang dialami guru, baik yang diselenggaran oleh pemerintah maupun mandiri. Unsur ini bisa menjadi kajian pada penelitin berikutnya.

Tugas guru dalam lingkungan pembelajaran daring adalah menciptakan lingkungan 
belajar yang mendukung kegiatan pembelajaran yang sesuai untuk mencapai hasil belajar yang diinginkan bersama. Kuncinya adalah semua komponen dalam sistem pengajaran, baik kurikulum, media pembelajaran, hasil belajar yang diinginkan, metode pengajaran yang digunakan, maupun evaluasi pembelajaran yang digunakan harus selaras satu sama lainnya (Biggs, 2013). Dalam konteks pembelajaran daring, baik pembelajaran daring penuh (full online learning) maupun pembelajaran campuran (blended learning) siswa akan berkolaborasi dengan rekan sejawatnya maupun sumber belajar daring lainnya untuk membangun pembelajarannya sendiri melalui aktivitas pembelajaran yang relevan (Amin, 2017).

Pertanyaan lain yang muncul adalah mengapa bukan faktor usia yang paling berpengaruh dalam peguasaan komputer dalam strategi pembelajaran daring, seperti penjelasan dari Prensky, (2001). Namun pernyataan yang menjadikan usia atau tahun lahir oarng bisa menjadi indikator kefasihan seseorang dengan teknologi informasi banya ditentang (Brown \& Czerniewicz, 2010; Jones \& Czerniewicz, 2010). Digital natives dan digital immigrants tidak bisa menjadi parameter baku karena manusia tidak bisa dikotakkan hanya oleh faktor usia saja. Terdapat faktor lain yang mempengaruhi kefasihan seseorang terhadap teknologi informasi yaitu faktor psikologis, organisasi dan sosial (Wang et al., 2013). Factor psikologis ini banyak, bisa meliputi selfefficacy, self enxiety, maupun sikap terhadap internet (Sam et al., 2005). Penelitian mereka juga menentang bahwa faktor gender berpengaruh pada sikapnya terhadap teknologi informasi. Faktor psikologis lain yang mempengaruhi sikapnya terhadap teknologi informasi adalah Perceived usefulness, dan perceived ease of use telah diteliti sejak lama (Davis, 1989). Kedua faktor subyektif tersebut berkorelasi terhadap perilaku pengguna teknologi informasi. Penjelasan di atas membuktikan bahwa factor usia tidak secara langsung berpengaruh terhadap tingkat penguasaan komputer dalam pembelajaran daring. Persoalan psikologis yang kompleks lagi terkait dengan self regulated learning. Guru sebagai pembelajar yang memiliki tingkat self regulated learning tinggi akan mampu belajar mandiri lebih baik dalam lingkungan pembelajaran daring (Santosa, Degeng, Sulton, \& Kuswandi, 2020; Dörrenbächer \& Perels, 2016; Reimann \& Bannert, 2019). Jadi, usia bukanlah faktor yang menentukan tingkat peguasaan komputer dalam strategi pembelajaran daring.

\section{SIMPULAN}

Berdasarkan hasil analisis dan pembahasan dalam penelitian ini, maka dapat disimpulkan bahwa: satu, terdapat pengaruh usia guru $\left(\mathrm{X}_{1}\right)$, pengalaman mengajar $\left(\mathrm{X}_{2}\right)$, dan internet self-efficacy $\left(\mathrm{X}_{3}\right)$ secara bersama sama terhadap tingkat penguasaan komputer dalam pembelajaran daring. Model regresi logistik ordinal yang terbentuk untuk tingkat penguasaan guru dalam pembelajaran daring adalah

$$
\begin{aligned}
& Y_{1}(X)=5.29+0.033 X_{1}-0.5 X_{4}-0.03 X_{\Xi} \\
& Y_{2}(X)=3.88+0.033 X_{1}-0.5 X_{4}-0.03 X_{\Xi} \\
& Y_{3}(X)=3.06+0.033 X_{1}-0.5 X_{4}-0.03 X_{\Xi} \\
& Y_{q}(X)=1.75+0.033 X_{1}-0.5 X_{4}-0.03 X_{3}
\end{aligned}
$$

Kedua, faktor yang paling berpengaruh terhadap tingkat penguasaan guru dalam pembelajaran daring adalah variabel pengalaman mengajar dari guru $\left(X_{2}\right)$.

Kontribusi penelitian ini bagi penelitian strategi pembelajaran daring bagi guru adalah perlu diberikan manipulasi pengalaman mengajar berbantuan komputer bagi guru dalam lingkungan pembelajaran daring. Untuk meningkatkan kualitas pengalaman mengajar guru perlu mendapatkan pendidikan dan pelatihan (Diklat) berkualitas terkait dengan pembelajaran daring. Diklat yang dimaksud 
seperti diklat menggunakan learning managemet system (LNS) Google classroom, Edmodo, Microsoft Teams atau yang lainnya. Juga diklat menyusun rencana plaksanaan pembelajaran (RPP) daring, bahan ajar daring, evaluasi pembelajaran daring, dan manajemen kelas daring.

Saran bagi peneliti selanjutnya adalah sebagai berikut: penelitian ini membutuhkan tindak lanjut dengan menambahkan beberapa variable bebas lain terkait dengan karakteristik guru yang bisa mempengaruhi tingkat peguasaan komputer guru dalam strategi pembelajaran daring. Variable lain yang dimaksud antara lain sarana dan prasarana belajar daring, dukungan orang tua siswa serta kebijakan sekolah (Herliandry et al., 2020). Dengan tambahan variable bebas tersebut pemahaman mengenai factor yang signifikan mempengaruhi tingkat peguasaan komputer guru dalam strategi pembelajaran daring akan lebih jelas.

\section{DAFTAR RUJUKAN}

Amin, A. K. (2017). Kajian Konseptual Model Pembelajaran Blended Learning berbasis Web untuk Meningkatkan Hasil Belajar dan Motivasi Belajar. Jurnal Pendidikan Edutama.

Amin, A. K., \& Mayasari, N. (2015). Pengembangan Media Pembelajaran Berbentuk Aplikasi Android Pengembangan Media Pembelajaran. Magistra.

Bancroft, D. (2014). Learning from experience. In Practical Leadership in Nursing and Health Care: A MultiProfessional Approach. https://doi.org/10.1201/b16629

Biggs, J. (2013). Aligning teaching for constructing learning (online).

Blackwell, C. K., Lauricella, A. R., \& Wartella, E. (2014). Factors influencing digital technology use in early childhood education. Computers

and

Education.

https://doi.org/10.1016/j.compedu.20

14.04.013

Boud, D., Keogh, R., \& Walker, D. (2013). Reflection: Turning experience into learning. In Reflection: Turning Experience into Learning. https://doi.org/10.4324/97813150590 51

Bransford, J. D., Brown, A. L., \& Cocking, R. R. (2000). How People Learn: Brain, Mind, Experience, and School. In Committee on learning research and educational practice. https://doi.org/10.1016/08852014(91)90049-J

Brown, C., \& Czerniewicz, L. (2010). Debunking the "digital native": Beyond digital apartheid, towards digital democracy. Journal of Computer Assisted Learning. https://doi.org/10.1111/j.13652729.2010.00369.x

Cassidy, S., \& Eachus, P. (2002). Developing the computer user selfefficacy (CUSE) scale: Investigating the relationship between computer self-efficacy, gender and experience with computers. Journal of Educational Computing Research. https://doi.org/10.2190/JGJR-0KVLHRF7-GCNV

Compeau, D. R., \& Higgins, C. A. (1995). Computer self-efficacy: Development of a measure and initial test. MIS Quarterly: Management Information Systems. https://doi.org/10.2307/249688

Daniel, S. J. (2020). Education and the COVID-19 pandemic. Prospects. https://doi.org/10.1007/s11125-02009464-3

Davis, F. D. (1989). Perceived usefulness, perceived ease of use, and user acceptance of information 
technology. MIS Quarterly: Management Information Systems. https://doi.org/10.2307/249008

Dörrenbächer, L., \& Perels, F. (2016). Selfregulated learning profiles in college students: Their relationship to achievement, personality, and the effectiveness of an intervention to foster self-regulated learning. Learning and Individual Differences, 51.

https://doi.org/10.1016/j.lindif.2016.0 9.015

Ertmer, P. A., Evenbeck, E., Cennamo, K. S., \& Lehman, J. D. (1994). Enhancing self-efficacy for computer technologies through the use of positive classroom experiences. Educational Technology Research and Development. https://doi.org/10.1007/BF02298094

Heinssen, R. K., Glass, C. R., \& Knight, L. A. (1987). Assessing computer anxiety: Development and validation of the Computer Anxiety Rating Scale. Computers in Human Behavior. https://doi.org/10.1016/07475632(87)90010-0

Herliandry, L. D., Nurhasanah, N., Suban, M. E., \& Kuswanto, H. (2020). Pembelajaran Pada Masa Pandemi Covid-19. JTP - Jurnal Teknologi Pendidikan. https://doi.org/10.21009/jtp.v22i1.15 286

Hill, T., Smith, N. D., \& Mann, M. F. (1987). Role of Efficacy Expectations in Predicting the Decision to Use Advanced Technologies: The Case of Computers. Journal of Applied Psychology. https://doi.org/10.1037/00219010.72.2.307

Hills, M. K. (2010). Digital natives and immigrants: The role of student attitudes towards technology on attrition and persistence in professional military education online distance learning environments.

Igbaria, M., \& Iivari, J. (1995). The effects of self-efficacy on computer usage. Omega. https://doi.org/10.1016/03050483(95)00035-6

Jaber, W., \& Moore, D. (1999). A Survey of Factors Which Influence Teachers' Use of Computer-Based Technology. International Journal of Instructional Media, 26(3), 253-266.

Jones, C., \& Czerniewicz, L. (2010). Describing or debunking? The net generation and digital natives. Journal of Computer Assisted Learning. https://doi.org/10.1111/j.13652729.2010.00379.x

Kim, Y., \& Glassman, M. (2013). Beyond search and communication: Development and validation of the Internet Self-efficacy Scale (ISS). Computers in Human Behavior. https://doi.org/10.1016/j.chb.2013.01 .018

Moos, D. C., \& Azevedo, R. (2009). Learning with computer-based learning environments: A literature review of computer self-efficacy. Review of Educational Research. https://doi.org/10.3102/00346543083 26083

Mumtaz, S. (2000). Factors affecting teachers' use of information and communications technology: A review of the literature. Journal of Information Technology for Teacher Education. https://doi.org/10.1080/14759390 000200096

Pentury, T., Aulele, S. N., \& Wattimena, R. (2016). Analisis Regresi Logistik Ordinal. Barekeng: Jurnal Ilmu Matematika Dan Terapan. 
https://doi.org/10.30598/barekengvol 10iss1pp55-60

Prensky, M. (2001). Digital Natives, Digital Immigrants Part 1. On the Horizon. https://doi.org/10.1108/10748120110 424816

Ramsden, P. (1991). A Performance Indicator of Teaching Quality in Higher Education: The Course Experience Questionnaire. Studies in Higher Education. https://doi.org/10.1080/03075079112 331382944

Reimann, P., \& Bannert, M. (2019). SelfRegulation of Learning and Performance in Computer-Supported Collaborative Learning Environments. In Handbook of SelfRegulation of Learning and Performance (pp. 285-303). https://doi.org/10.4324/97813156970 48-19

Sadikin, A., \& Hamidah, A. (2020). Pembelajaran Daring di Tengah Wabah Covid-19. BIODIK. https://doi.org/10.22437/bio.v6i2.975 9

Sam, H. K., Othman, A. E. A., \& Nordin, Z. S. (2005). Computer self-efficacy, computer anxiety, and attitudes toward the Internet: A study among undergraduates in Unimas. Educational Technology and Society.

Santosa, E. B., Degeng, I. N. S., Sulton, \& Kuswandi, D. (2020). The effects of mobile computer-supported collaborative learning to improve problem solving and achievements. Journal for the Education of Gifted Young Scientists. https://doi.org/10.17478/jegys.65664 2

Torkzadeh, G., \& Koufteros, X. (1994). Factorial validity of a computer selfefficacy scale and the impact of computer training. Educational and Psychological Measurement. https://doi.org/10.1177/00131644940 54003028

Wahlstrom, K. L., \& Louis, K. S. (2008). How teachers experience principal leadership: The roles of professional community, trust, efficacy, and shared responsibility. Educational Administration Quarterly. https://doi.org/10.1177/0013161X08 321502

Wang, Q., Myers, M. D., \& Sundaram, D. (2013). Digital natives and digital immigrants: Towards a model of digital fluency. Business and Information Systems Engineering. https://doi.org/10.1007/s12599-0130296-y

Yeşilyurt, E., Ulaş, A. H., \& Akan, D. (2016). Teacher self-efficacy, academic self-efficacy, and computer self-efficacy as predictors of attitude toward applying computer-supported education. Computers in Human Behavior.

https://doi.org/10.1016/j.chb.2016.07 .038 . 